\title{
Представљање старих књига у Дигиталној Библиотеци Матице српске: поводом јубилеја десет година Дигиталне БМС
}

\author{
Александра Драпшин \\ Библиотека Матице српске, Нови Сад \\ adrapsin@bms.ns.ac.rs
}

\begin{abstract}
Сажетак
Веб-презентација Диіитална БМС постављена је на интернет 20. септембра 2011. За десет година рада, у базу података укупно је укључено 31.555 публикација (1.746.908 страница). Данас је она једна од највећих дигиталних библиотека у Србији. Стара библиотечка грађа окупљена је у девет колекција које прате постојеће збирке Библиотеке Матице српске (БМС). Дигитализовано је 4066 примерака старих рукописних и штампаних књига. Најбројнија је колекција Срйске књиїе og 1801. go 1867. Іоgине, са 2741 примерком грађе. Дела Вука Стефановића Караџића бележе највише прегледа у целој дигиталној библиотеци, а међу њима се истиче Живой и обичаји нароgа срйскоі̆а (Беч, 1867), посећено 16.185 пута. Велики број посета имају и дела Доситеја Обрадовића, Јована Рајића, Захарије Орфелина, Буре Даничића и других. Повезивањем дигиталне копије са електронским и штампаним каталогом, корисницима се пружају и додатне информације о културном добру. Презентација Диіийална БМС омогућила је приступ српском културном наслећу широм света.
\end{abstract}

Кључне речи: Диіитална БМС, старе рукописне књиге, старе штампане књиге, стара библиотечка грађа, раритети, дигитализација, дигиталне библиотеке

\section{Увод}

Библиотека Матице српске, најстарија српска библиотека националног значаја и прва јавна и научна библиотека код Срба, данас има око четири милиона публикација. У својим фондовима чува вредне колекције старих и ретких књига, стваране и попуњаване од настанка Библиотеке 1826. године до данас.

У Електронском каталогу БМС, ${ }^{1}$ започетом 1989. године, има милион и по записа (књиге, наслови периодике, посебне збирке, аналитичка обрада часописа). ${ }^{2}$

Дигитализација збирки Библиотеке наставак је дугогодишњих напора на прикупљању, чувању, заштити, каталошко-библиографској обради и презентацији њених фондова. У савременом информатичком друштву један од најважнијих задатака јесте да се омогући универзални приступ културној и научној баштини коју библиотеке поседују.

Дигитализација грађе у БМС започета је 2006. године. У то време снимане су, на првом месту, старе и ретке књиге у циљу заштите. Настали дигитални документи чувани су на компактдисковима који су смештени у Магацину раритета.

\footnotetext{
1 Електронски каталог Библиотеке Матице српске, преузето 30. 9. 2021, https://plus.sr.cobiss.net/opac7/bib/search.

2 „Извештај о раду Библиотеке Матице српске за 2020. годину”, Гоgишњак Библиобеке Машиие срӣске: за 2020. (2021): 13
} 
Године 2010. набављена је нова опрема, израђени софтвер за презентацију и рачунарски програм за унос метадопадата и описе публикација, чиме је омогућено брже, једноставније и обимније снимање библиотечке грађе. Веб-страница Диїишална БМС постављена је 20. септембра 2011. ${ }^{3}$ Од тада је база података континуирано попуњавана. У презентацију је до краја септембра 2021. укупно укључено 31.555 публикација (1.746.908 страница). ${ }^{4}$ Данас је она једна од највећих дигиталних библиотека у Србији.

Од самих почетака, пројекат је био усмерен на заштиту и представљање највреднијег фонда Библиотеке. У том смислу, приоритет је имала стара и ретка библиотечка грађа. Нове технологије омогућиле су да се физички заштитите културна добра и, поред већ постојећих микрофилмова, израде њихове дигиталне копије. Путем интернета, драгоцене збирке Библиотеке постале су доступне широком кругу читалаца.

Стручњаци БМС дуги низ година и с великом посвећеношћу радили су на обради и презентацији најстаријег дела фонда. Сви примерци старе библиотечке грађе прошли су каталошко-библиографску обраду. Све српске књиге од 13. века до 1867. и раритетне стране књиге налазе се у Електронском каталогу. Поред тога, у настојањима да се вредни фондови стручно прикажу и приближе јавности, истрајно се радило на објављивању штампаних каталога грађе. Публикације су представљене у каталозима, који од 1988. излазе у следећим едицијама: Ћирилске рукойисне књиї БМС (18 томова), Кайалої сйарих и решеких књиїа БМС (8 томова) и

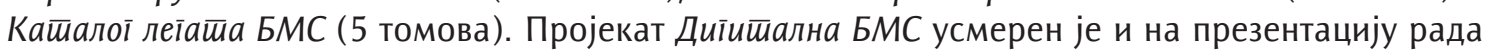
стручњака Библиотеке, а повезивањем дигиталне копије са електронским и штампаним каталогом, читаоцима се пружају и друге додатне информације о културном добру.

\section{Колекције старих књига у Диїийалној БМС}

Колекције Диїишалне БМС формирају се према постојећим збиркама Библиотеке и сада их има 24. Њихов број током десет година се увећавао. Старе књиге презентоване су у девет колекција: Рукойисне књиїе, Срйске књиї 15-17. века, Срйске књиї 18. века, Срйске књиїе оg 1801.

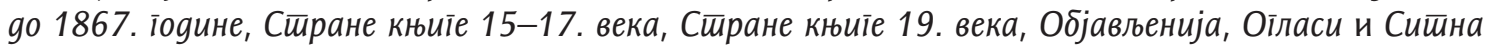
шйамйана ірађа. Старе периодичне и повремене публикације налазе се у збиркама: Каленgари и месеиослови, Часойиси и Новине. Основу сваке дигиталне колекције чине збирке раритета, које се допуњавају примерцима из библиотека целина и личних библиотека.

Библиотека Матице српске има богату збирку рукописа у којој се налази 707 књига различите провенијенције, а највреднији су ћирилски рукописи (492) из времена од 13. до 19. века. ${ }^{5}$ Приоритет у дигитализацији имале су књиге чији су каталошки описи објављени у едицији Ћирилске рукойисне књиїе БМС ${ }^{6}$ и до септембра 2021. снимљено је 123 рукописа, а њихове дигиталне копије повезане су са описима у штампаном каталогу. Библиотека је набавила нову опрему која омогућава брже и квалитетније снимање ове специфичне грађе, што ће олакшати дигитализацију и осталих примерака. Најстарија књига у Библиотеци, Майичин айосӣол, писан на пергаменту у 13. веку, има и највише прегледа у колекцији (3523). Читаоци су с великим интересовањем

\footnotetext{
${ }^{3}$ Новка Шокица Шуваковић, „Дигитална БМС", Годишњак Библиошеке Машиие срӣске: за 2011. (2012): 128.

${ }^{4}$ Диіитална БМС, преузето 30. 9. 2021, www.digital.bms.ns.ac.rs.

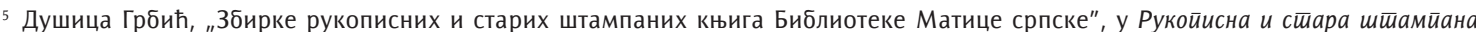
књиіа: зборник раgова, ур. Душица Грбић, Светлана Вучковић и Александра Драпшин (Београд: Заједница матичних библиотека Србије; Нови Сад: Библиотека Матице српске, 2018), 325.

6 У серији Ћирилске рукойисне књиіе Библиойеке Машиице срйске тематским редоследом објављено је осамнаест књига: 1. Јеванђеља

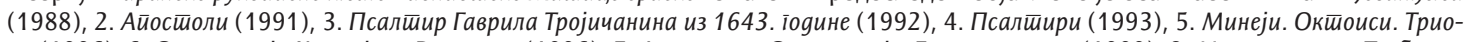

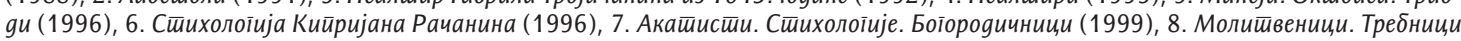
(2001), 9. Беикеречки шийик из 14. века (2003), 10. Служабниии. Часослови (2004), 11. Зборниии (2006), 12. Поученија (2007), 13.

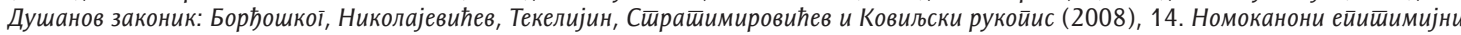

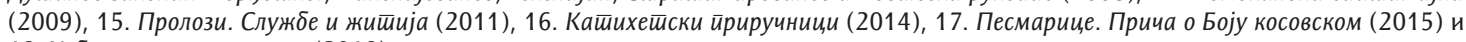
18. уијеници и ирриручници (2018)
} 
користили и друге значајне рукописе из фонда: Душанов законик: Ковиљски рукойис из 1726, Беч-

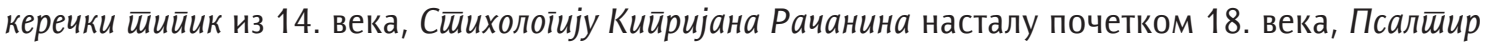
Гаврила Тројичанина писан у Манастиру Света Тројица код Пљеваља 1643. године и остале.

У Библиотеци Матице српске постоји највећа збирка штампаних србуља, од Окйоиха йрвоіласника из 1493/1494. до Псалйира с йослеgовањем из 1643. іоgине - 146 примерака, 31 издање (од око 40 познатих издања). „То су православне и верске књиге на српскословенском језику, објављене на Цетињу (по неким предањима и на Ободу), у Горажду, Венецији, у манастирима Рујну, Грачаници, Милешеви, Мркшиној цркви, у Београду, Скадру, а неке и у Румунији“. ${ }^{7}$ У Диїиталној БМС окупљене су у колекцији Срйске књиїе 15-17. века, у којој има 16 публикација, а њихови описи налазе се и у штампаном каталогу. ${ }^{8}$ Снимање издања из ове збирке је у току. Најчитанија књига у дигиталној колекцији истовремено је и најстарија - Окйоих ирвоїласник Ђурђа Црнојевића из 1493/94. іоgине (4331 преглед), а следе Молишивеник (Требник) из 1546. штампан у манастиру Милешева и Зборник за иууинике (Часловаи) из 1566. отиснут у Венецији.

„Збирке српских штампаних књига и периодике 18. и 19. века највеће су такве збирке на

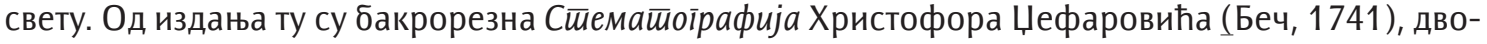
томно Жишије Пешира Великоі Захарије Орфелина (Венеција, 1772. и илустровано издање из 1774) и друга његова дела, четворотомна Нсшорија Јована Рајића (Беч, 1794-1795), дела Доситеја Обрадовића, Вука Стефановића Караџића, Петра II Петровића Његоша, Ђуре Даничића, Лукијана Мушицког, Бранка Радичевића и других српских писаца“. ${ }^{9}$

У дигиталној колекцији Срйске књиїе 18. века презентована је целокупна збирка штампаних издања, а укупно их је унето 280. Снимљени су најбоље очувани примерци и укључене варијанте издања. 3бирка је представљена и у штампаном каталогу. ${ }^{10}$ Коришћење дигиталних копија показује да су највише читана дела Доситеја Обрадовића, Захарије Орфелина и Јована

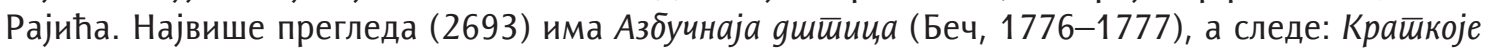
ввеgеније в истиорију йроисхожgенија славено-серйскаїо нароgа Павла Јулинца (Венеција, 1765), Исшорија разних славенских нароgов..., част 2, Јована Рајића (Беч, 1794), Плач Сербији Захарије Орфелина (Венеција, 1762-1763) и Избранне басне Доситеја Обрадовића (Будим, 1800).

Колекција Срйске књиїe og 1801. gо 1867. іоgине је најбројнија, са 2741 примерком грађе. Дигитализована су сва издања описана у тротомном штампаном каталогу и од сваког издања снимљен је најбоље очувани примерак. ${ }^{11}$ Дела Вука Стефановића Караџића имају највише посета у целој дигиталној библиотеци, а не само међу старим књигама. Најчитанија је књига (16.185 прегледа) Животи и обичаји нароgа срйскоїа (Беч, 1867), а велики број листања бележе и Писмении, серйскоїа језика (Беч, 1814) и издања Срӣскої рјеиника (Беч, 1818. и Беч, 1852).

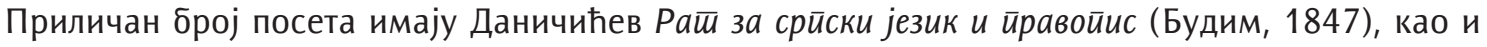
дела Павла Соларића, Јована Рајића, Јована Стерије Поповића, Јоакима Вујића, Петра II Петровића Његоша и других.

Осим старих српских књига, у БМС постоје богате збирке страних публикација од 15. до 17. века, штампаних на разним језицима (на грчком, латинском, француском, немачком, италијанском, мађарском итд.). Међу њима је 16 инкунабула - књига отиснутих до краја 15. века.

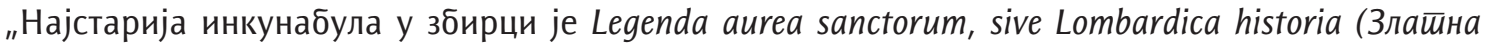
леїенgа) Јакобуса де Ворагина, објављена у немачком граду Улму 1477. године (неки каталози

\footnotetext{
7 Грбић, „Збирке рукописних и старих штампаних књига Библиотеке Матице српске”, 331.

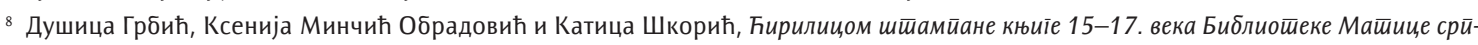
ске (Нови Сад: Библиотека Матице српске, 1994).

9 Грбић, „Збирке рукописних и старих штампаних књига Библиотеке Матице српске”, 332.

10 Мирјана Брковић, Срйске књиїе и иериоgика 18. века Библиоиееке Машиице срйске (Нови Сад: Библиотека Матице српске, 1996).

11 Финка Пјевач и Јасна Карталовић, ред., Срйске књиіе Библиошеке Машиице срйске: 1801-1867, том 1 А-Љ (Нови Сад: Библиотека Матице српске, 2005); Финка Пјевач и Јасна Карталовић, ред., Срйске књиїе Библиоиееке Майице срӣске: 1801-1867, том 2 М-Г

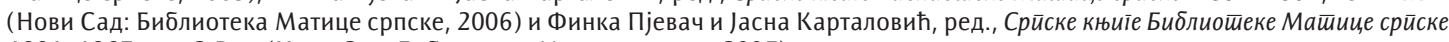
1801-1867, том 3 P-Ө (Нови Сад: Библиотека Матице српске, 2007)
} 
наводе и податак око 1481. іоguне)“.'2 Међу књигама 16. и 17. века посебно су вредне елзевире - издања чувене холандске породице Елзевир као и алgине - издања венецијанског штампара Алда Мануција и његових следбеника.

У дигиталној колекцији Сш̄ране књиї 15-17. века има 228 публикација и снимање издања из збирке и даље траје. Најчитаније су инкунабуле Sermones de sanctis Јакобуса де Ворагина (Аугзбург, 1484) са 1593 прегледа и Космоірафија Птолемеја Клаудија (Улм, 1486), која је листана 1502 пута. Корисницима су такође занимљива дела Франческа Петрарке, Публија Корнелија Тацита и Луција Анеја Сенеке.

Колекција Сширане књиї 18-19. века има 26 публикација. Нису сви примерци ове збирке дигитализовани, па се снимање наставља.

Ситна штампана грађа БМС до 1867. године презентована је у три колекције. Збирка Објављенија има 215 примерака. Настала крајем 18. века, објављенија су штампана као својеврсни огласи којима су се писци или издавачи књига и уредници часописа обраћали читалачкој публици. Збирка Оїласи даје на увид све прве примерке огласа од 1803. до 1867. и дигитализо-

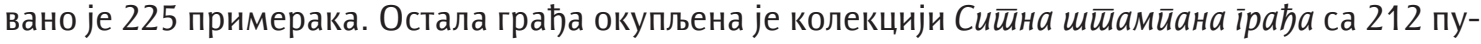
бликација. ${ }^{13}$ Снимљена су сва издања описана у штампаним каталозима. ${ }^{14}$ Неке од читанијих

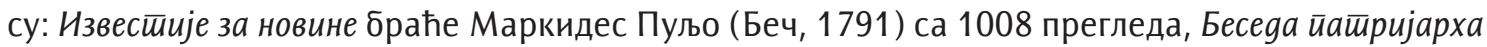
Јосифа Рајачића на ошвварању Сабора 1861. у Сремским Карловиима (Сремски Карловци, 1861) са 1156 и Писмо захвалносии Саве Текелије Јовану Чокрљану (Арад, 1842) које бележи 1274 посете.

За десет година рада, укупно је дигитализовано 4066 примерака старих рукописних и штампаних књига и ситне штампане грађе на српском и другим језицима.

Дигитализацијом је до сада обухваћен и велики број старих периодичних и повремених публикација. Могу се издвојити прве српске новине Серйскија йовсеgневнија новини (Беч, 1791-

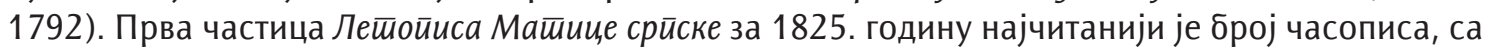
укупно 12.588 листања. Снимање серијских публикација се наставља, а избор наслова врши се на основу више критеријума.

Приликом снимања раритетне грађе бирани су најбоље очувани примерци издања сваке колекције, а укључене су и варијанте издања. Уколико скенирана публикација није комплетна, снимани су и други примерци. У све послове дигитализације укључен је већи број библиотекара и књижничара, стручни радници на снимању публикација, информатичари, конзерватори и рестауратори.

\section{Опис и претраживање публикација у Диїийалној БМС}

У мрежном софтверу Диїйалне БМС постоји део за опис све врсте грађе где се уписују метаподаци. Преко COBISS-ID броја ${ }^{15}$ може се приступити Електронском каталогу.

Наслови публикација старе библиотечке грађе штампани грађанском и црквеном ћирилицом уносе се савременим правописом и писмом. За називе места издања, издавача и штампара уписују се јединствени називи усвојени приликом израде регистара за штампане каталоге, одакле се преузимају као метаподаци. Намера је да се корисницима омогући лакши приступ и претраживање дигиталних објеката. Каталошки опис публикације у формату листића садржи линк који повезује дигитални запис са описом примерка у штампаном каталогу.

\footnotetext{
12 Грбић, „Збирке рукописних и старих штампаних књига Библиотеке Матице српске”, 330.

13 Диїитална БМС.

14 Јасна Карталовић, ред., Објављенија Библиошееке Машиице срӣске: 1791-1866. (Нови Сад: Библиотека Матице српске, 2008); Јасна Карталовић, ред., Сишина шишамйана ірађа Библиоеиеке Машиице срйске: 1801-1867. (Нови Сад: Библиотека Матице српске, 2012); Јасна Карталовић и Светлана Вучковић, ред., Оїласи Библиошеке Машиице срйске: 1803-1867. (Нови Сад: Библиотека Матице српске, 2010).

15 Идентификациони број у систему COBISS - Кооперативни онлајн систем и сервиси.
} 
У записе Електронског каталога БМС уноси се линк путем којег се лако приступа дигиталној копији. На овај начин су две базе међусобно повезане. ${ }^{16}$

Публикације се могу прегледати по колекцијама, постоје једноставна и напредна претрага, где је омогућено претраживање по основним особинама описа као што су наслов, аутор, издавач, година и место издавања, језик, предметне одреднице, сигнатура и садржај.

Годишњи број посета увећавао се са растом дигиталне библиотеке. У 2020. години Диіишалну БМС посетило је 39.229 корисника са свих континената (68.592 посете) који су прегледали 311.662 веб-странице. Укупно су забележена 3.752.242 листања публикација. ${ }^{17}$

\section{Закључак}

Презентација Диїишална БМС постављена је на интернет 11. септембра 2011. гоине. Пројекат је од почетка био усмерен на заштиту и представљање највреднијег фонда Библиотеке и приоритет је имала стара библиотечка грађа.

Збирке старих књига окупљене су у девет колекција. За десет година рада укупно је дигитализовано 4066 примерака старих рукописних и штампаних књига и ситне штампане грађе на српском и другим језицима. Основу сваке дигиталне колекције чине постојеће збирке раритетне грађе, а допуњавају се примерцима из библиотека целина и личних библиотека.

До сада су дигитализована сва издања српских књига и ситне штампане грађе од почетка 18. века до 1867. године, која су описана у штампаним каталозима поменутих збирки. Дигитализација рукописних књига, штампаних србуља и страних књига од 15. до 19. века ће се наставити.

У Диіитиалној БМС најбројнија је колекција Срйске књиїе og 1801. go 1867. їoguне, са 2741 примерком грађе. Дела Вука Стефановића Караџића најинтересантнија су читаоцима и бележе највиши број прегледа у целој дигиталној библиотеци, а међу њима се истиче Живош и обичаји нароgа срйскоїа (Беч, 1867) посећено 16.185 пута. Велики број посета имају и дела Доситеја Обрадовић, Јована Рајића, Захарије Орфелина, Буре Даничића и других. Показало

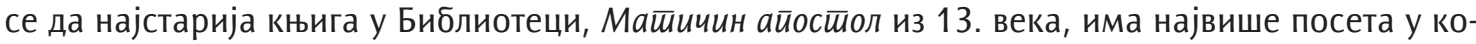

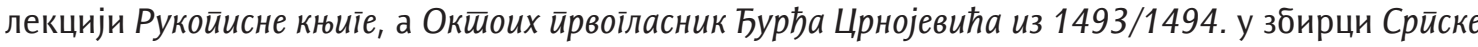
књиіе 15-17. века. На број читања није у великој мери утицало од када се публикација налази у дигиталној колекцији.

Презентација Диїйална БМС омогућила је приступ културним добрима заинтересованим читаоцима широм света. Научним истраживачима, поред листања публикације, представљени су описи у електронском каталогу и детаљнији описи у штампаним каталозима, што је учинило живим и блиским писане трагове наше прошлости. Може се закључити да Диїишална БМС доприноси популаризацији културног наслеђа Србије, памћењу и откривању извора наше књижевности, културе и духовности.

\section{Литература и извори:}

1. Brković, Mirjana. Srpske knjige i periodika 18. veka Biblioteke Matice srpske. Novi Sad: Biblioteka Matice srpske, 1996.

2. Elektronski katalog BMS. Preuzeto 30. 9. 2021. https://plus.sr.cobiss.net/opac7/bib/search.

3. Grbić, Dušica. „Zbirke rukopisnih i starih štampanih knjiga Biblioteke Matice srpske”. U Rukopisna i stara štampana knjiga: zbornik radova. Urednice Dušica Grbić, Svetlana Vučković i Aleksandra Drapšin, 324-342. Beograd: Zajednica matičnih biblioteka Srbije; Novi Sad: Biblioteka Matice srpske, 2018.

\footnotetext{
16 Шокица Шуваковић, „Дигитална БМС", 130-132.

17 „Извештај о раду Библиотеке Матице српске за 2020. годину”: 34
} 
4. Grbić, Dušica, Ksenija Minčić Obradović i Katica Škorić. Ćirilicom štampane knjige 15-17. veka Biblioteke Matice srpske. Novi Sad: Biblioteka Matice srpske, 1994.Digitalna Biblioteka Matice srpske. Preuzeto 30. 9. 2021. http://digital.bms.rs/ebiblioteka/publications.

5. "Izveštaj o radu Biblioteke Matice srpske za 2020. godinu". Godišnjak Biblioteke Matice srpske: za 2020. (2021): 9-44.

6. Kartalović, Jasna, red. Objavljenija Biblioteke Matice srpske: 1791-1866. Novi Sad: Biblioteka Matice srpske, 2008.

7. Kartalović, Jasna, red. Sitna štampana građa Biblioteke Matice srpske: 1801-1867. Novi Sad: Biblioteka Matice srpske, 2012.

8. Kartalović, Jasna i Svetlana Vučković, red. Oglasi Biblioteke Matice srpske: 1803-1867. Novi Sad: Biblioteka Matice srpske, 2010.

9. Pjevač, Finka i Jasna Kartalović, red. Srpske knjige Biblioteke Matice srpske: 1801-1867. Tom 1 A-LJ. Novi Sad: Biblioteka Matice srpske, 2005.

10. Pjevač, Finka i Jasna Kartalović, red. Srpske knjige Biblioteke Matice srpske: 1801-1867. Tom 2 M-P. Novi Sad: Biblioteka Matice srpske, 2006.

11. Pjevač, Finka i Jasna Kartalović, red. Srpske knjige Biblioteke Matice srpske: 1801-1867. Tom 3 R- $\theta$. Novi Sad: Biblioteka Matice srpske, 2007.

12. Šokica Šuvaković, Novka. „Digitalna BMS”. Godišnjak Biblioteke Matice srpske: za 2011. godinu (2012): 128-134.

\title{
Presentation of Old Books in the Digital MSL
}

\begin{abstract}
Summary
The Matica Srpska Library owns rich and valuable collections of old and rare books. Digitization, which was launched in 2006, is the continuation of the ongoing efforts of the experts of this library to collect, store, protect, describe, and present rare library materials. The Digital MSL web presentation was set up on September 20, 2011. During the last decade, a total of 31,555 publications (1,746,908 pages) have been entered into the database. At present, it is one of the largest digital libraries in Serbia. The digitization of old library materials was a priority from the very beginning. The 4,066 items of old manuscripts and printed books, as well as small prints, have been compiled in nine collections: Manuscripts, Serbian Books from the 15th to $17^{\text {th }}$ Century; Serbian Books in the $18^{\text {th }}$ Century; Serbian Books from 1801 to 1867; Foreign Books from the 15th to $17^{\text {th }}$ Century; Foreign Books from the 18 to $19^{\text {th }}$ Century; Announcements; Ads; Small Prints. The most numerous collection, which comprises 2,741 items, is Serbian Books from 1801 to 1867. The works of Vuk Stefanović Karadžić have had the largest number of views, not only among the old books but in the entire Digital Library. The most frequently read book is Life and Customs of the Serbian People (Vienna, 1867), with 16,185 views. The works of Dositej Obradović, Jovan Rajić, Zaharije Orfelin, Đura Daničić, and others have had a large number of views as well. Linking digital copies with the electronic and printed catalogues provides additional information about the stored cultural goods for the users. The Digital MSL presentation has given global access to the Serbian cultural heritage.
\end{abstract}

Keywords: Digital MSL, old manuscripts, old printed books, old library materials, rarities, digitization, digital libraries 